\title{
Europe is urged to hold back on xenotransplant clinical trials
}

[PARIS] The parliamentary assembly of the Council of Europe is expected to vote tomorrow (29 January) in favour of a moratorium on clinical trials of xenotransplantation.

The assembly, a political body with members from 40 European countries, is expected to say that trials of transplanting animal organs, tissues and cells into humans should be stopped until the risk of creating new pandemics have been better assessed.

Its views have some support in the scientific community. But many in the biomedical industry are keen to see clinical trials proceed and argue that, although there are dangers, enough is known to contain them.

The vote marks the first time that the

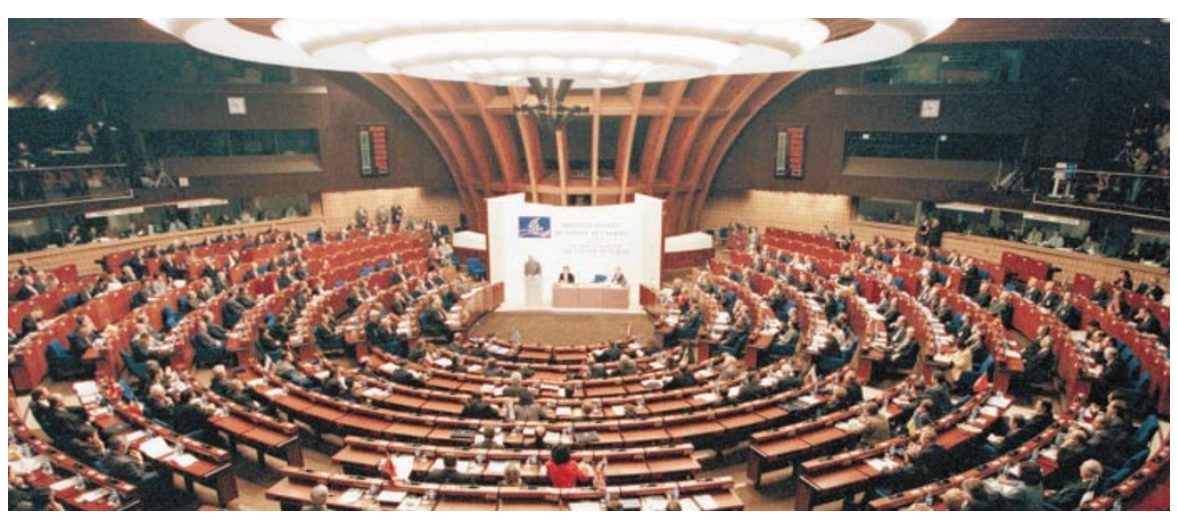

Body politic: the Council of Europe will discuss the potential dangers of man-made pandemics. long-simmering debate - whether xenotransplantation should cross the Rubicon from animal studies into the clinic — has been taken up by an international political body. Until now, discussion has been mainly restricted to scientific and regulatory bodies, the main exception being the United Kingdom, which has agreed to allow limited trials to proceed under strict supervision.

The motion, which was drafted by the council's committee on science and technology, states that a "host" of scientific, medical, legal, social, ethical and public-health questions must be debated "and satisfactory answers found" before clinical trials on humans can proceed.

The vote focuses on the remote but real danger of causing man-made pandemics. Any test of animal-to-human transplants inevitably involves an unwanted experiment: finding out whether animal viruses

might jump to graft recipients and then on to others (see Nature 391, 320-324; 1998).

The motion calls on the council to work towards a world-wide moratorium, since infectious diseases do not respect borders.

Technically, the European moratorium would have little legal weight. A positive vote would at most result, eventually, in a legally binding 'protocol' being added to the Council of Europe's Convention on Human Rights and Biomedicine (see Nature 389, 656; 1997). But unlike the 1953 European Convention on Human Rights, countries can choose to ratify protocols or to opt out.

Nonetheless, a unanimous adoption by the assembly would send a "powerful political signal to those in power from the representatives of the people, of our fears, our scepticism and our concern that ethical issues have not been amply discussed," says GianReno Plattner, the motion's rapporteur.

\section{Sequence 'terrorist genes', says Venter}

[LONDON] Governments should sequence genes with potential uses in biological weapons, according to Craig Venter, cofounder of Celera Genomics, the company which plans to sequence the whole human genome by 2001.

Such data, he argues, would allow researchers to rapidly detect biological including genetic - terrorism, and to design vaccines and drugs to prevent infection.

Venter's call was backed by Frank Young, a former adviser to President Clinton on bioterrorism, who is now a Presbyterian pastor. Both were speaking last week at a seminar at the annual meeting of the American Association for the Advancement of Science in Anaheim, California.

Young said it can take up to 72 hours to identify a particular organism. Knowing the gene sequence of all potential pathogens, he added, could reduce this to minutes.

Fears of a lack of preparedness to deal with a bioterrorist attack are echoed by warnings from the British Medical Association about the potential dangers from genetic weapons capable of targeting particular ethnic groups.

In Biotechnology, Weapons and Humanity, a report issued last week, the BMA said that while such weapons "are not currently a practical possibility, it would be complacent to assume that they could never be developed in the future".

The report calls for vigilance among scientists as it could be difficult to distinguish legitimate microbiology and gene-therapy research from work on developing biological weapons. Ehsan Masood
"The vote is an attempt to express the feelings of the populations of Europe rather than those of the experts and interested parties," says Plattner, a nuclear physicist and Swiss Socialist.

News of the council's intentions has shocked supporters of clinical trials.

Xenotransplant researcher Didier Houssin, head of the French transplant authority, condemned the motion as "out of touch". He said he had alerted the French government, a signatory to the council's Convention on Human Rights and Biomedicine, to the "risks" of adopting the protocol.

"We believe that the appropriate approach is regulation of xenotransplantation and broad public discussion on the issues," says Paul Herrling, scientific director of Novartis, the company with the largest stake in what industry analysts predict could be a $\$ 6$ billion market.

"A moratorium would only inhibit the scientific activities needed to solve the remaining problems before this new technology can be applied to patients."

The moratorium is also contested by Robin Weiss, the virologist at the Institute of Cancer Research in London who showed that pigs, the current donor of choice, harbour endogenous retroviruses (PERVs) that can infect human cells in vitro (see Nature 389, 681; 1997).

"Much of the research and evaluation of risk can only come from limited, phase I human clinical trials," Weiss says. "The recommendations are so restrictive as to be unworkable. They will impede the answers which the committee requires."

Daniel Salomon of Scripps Research Institute in California, a member of the board of the American Association of Transplant Physicians, says the evidence "does not suggest that preliminary, limited and well controlled trials would be dangerous 
to patients, professional staff or public."

Plattner says such criticisms miss the point. He says the council wants xenotransplantation research per se to be promoted. But he adds: "We are at the point where for economic reasons we are going to make irrevocable steps that we might regret. My attempt is a last-minute bid to get some breathing space to think twice about something we might find out later we didn't want to do."

Plattner's arguments are supported by Abdullah Daar, a transplant surgeon at the Sultan Qaboos University in the Sultanate of Oman, and chairman of the xenotransplantation advisory committee set up last year by the World Health Organization.

Daar argues that proceeding with xenotransplantation could be justified at present only if large numbers of patients could be saved in the near future and if a delay would not improve assessment of the risks. But the science is not yet ready to deliver therapeutic benefits, argues Daar. And trials in countries with well developed regulations would open the door for other countries, he says.

The council's move is welcomed by Fritz Bach, a xenotransplant scientist from Harvard Medical School, who has campaigned for an international moratorium on clinical trials. Before expert committees issue regulations, he says, there should be a wide "informed" public debate on whether clinical trials should be allowed to proceed at all (see Nature Med. 4, 142-145; 1998).

Jonathan Allan, a virologist at the Southwest Foundation for Biomedical Research in San Antonio, Texas and a member of the US Food and Drug Administration (FDA) advisory subcommittee on xenotransplantation, while critical of some of the scientific analysis of the council's report, admits: "You can always move forward, but it is near impossible to move backward, especially if one has unleashed a new viral infection."

Margaret Somerville, a bioethicist at McGill University, says: "The crucial issue in my view is who should decide on whether or not we go ahead with it. I believe that, ethically, it is essential that the public be involved."

She is also concerned that the University of Western Ontario and the University of Guelph have imported pigs from Novartis for what is being slated as an imminent multimillion-dollar series of clinical trials.

The FDA is revising draft Guidelines on Infectious Disease Issues in Xenotransplantations that would allow clinical trials, provided their organizers can "adequately" monitor for any subsequent animal infections. Plans for clinical trials in the United States are reported to be already under way.

Joel Kopple, president of the US National Kidney Foundation, says: "We believe the development of techniques for xenotransplantation should continue, but this should occur cautiously and with careful monitoring of the outcomes."

DeclanButler

\section{UK women lead the way on interdisciplinary research}

[LONDON] Women scientists spend more of their time doing interdisciplinary research than their male counterparts, yet are less likely than men to be team players, according to the results of a survey due to be published next month.

The survey was commissioned by several UK higher education funding bodies as part of their consultation on mechanisms for the next Research Assessment Exercise (RAE), due to begin in 2001. Because of the way departments are graded, many scientists believe that the survey, intended to measure the quality of research in individual university departments, inhibits interdisciplinary studies.

Almost three-quarters of the 5,675 scientists questioned said that they are involved in interdisciplinary research, defined as "projects that draw together people and knowledge from discrete fields". But in a range of subjects, from medical science to the humanities, women say that they spend more time on such projects than men (see graph).

The trend remains clear when broken down by age, and is even stronger if the amount of cross-field study is considered. Asked to classify their research against 574 subject fields, one in five women cited seven or more fields, compared with only one in ten men.

But there is one exception to this trend: engineering. "Women who enter research in this field seem to focus on narrow disciplinary work, much like their male colleagues," says Andy Boddington, director of Evaluation Associates who carried out the survey.

At present, 90 per cent of universitybased engineers are men, and Boddington thinks that the narrowness of the subject may be one reason for its failure to attract more women.

The comparative data provided by the

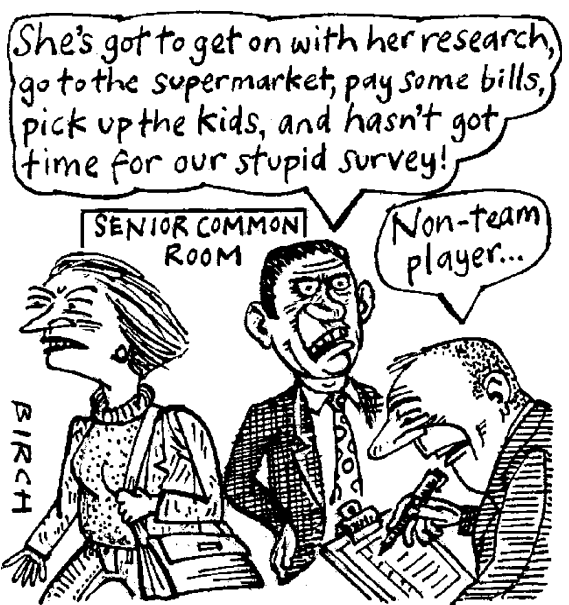

Æิఠ 1999 Macmillan Magazines Ltd

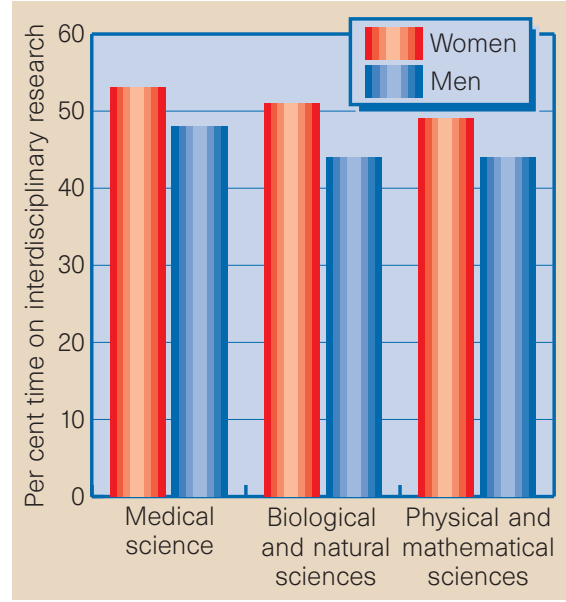

Crossing boundaries: women spend more time than men doing interdisciplinary research.

survey on the way men and women carry out research reveal that female academics are more likely to work alone - on average they spend one-third of their time on solo research - whereas men allocate just onefifth of their time to such work.

Gillian Evans, a mediaeval historian at the University of Cambridge whose work covers several disciplines, thinks this may be because women often feel excluded, seeing the workplace as a "men's club".

She adds that women are more likely to do interdisciplinary research because they have more intellectual freedom, "having nothing to lose" and being less tied by the "constraints of wanting to conform".

Another trend is the well-documented male bias in senior positions. According to data from the Higher Education Statistics Agency, in the academic year 1996-7 only 12 per cent of all professorships were held by women. The new survey reveals more women than men on short-term contracts.

One explanation for the imbalance is that it reflects the number of men and women who apply for research awards. For example, 71 per cent of women in the survey were submitted to the last RAE in 1996, compared with 86 per cent of the men.

Britain's six research councils and the Wellcome Trust reported a similar trend in 1997 (see Nature 390, 431; 1997), and next month they will jointly commission a survey to find out why.

"We are not certain why women should research differently to men," Boddington acknowledges. "What is surprising is how consistent the difference is." His colleague Trudy Coe believes this difference will turn out to be "not about tangible things, but about subtle social influences". Alison Mitchell 